\title{
Assessment of Undiscovered Oil and Gas Resources in the Midlands Area, England, 2018
}

Using a geology-based assessment methodology, the U.S. Geological Survey estimated mean undiscovered, technically recoverable resources of 319 million barrels of oil and 8.3 trillion cubic feet of gas in the Midlands area of England.

\section{Introduction}

The U.S. Geological Survey (USGS) completed an assessment of undiscovered, technically recoverable continuous (unconventional) and conventional oil and gas resources in the Midlands area of England (figs. 1 and 2). The Midlands is a structurally complex area as a result of several regional tectonic events (Fraser and Gawthorpe, 1990; Corfield and others, 1996). Extension in the Late Devonian to Carboniferous led to deposition of synrift organic-rich shales of the lower part of the Bowland Shale Formation and Hodder Mudstone Formation within several grabens. Postrift regional thermal subsidence led to the deposition of organic-rich shales in the upper part of the Bowland Formation and fluvial-deltaic sandstones of the Millstone Grit Group. Shales in the upper and lower parts of the Bowland and in the Hodder represent the most viable petroleum source rocks in the Midlands (Gross and others, 2015; Raji and others, 2015; Yang and others, 2016; Fauchille and others, 2017; Hennissen and others, 2017; Whitelaw and others, 2017). Regional, northdirected compression in the late Carboniferous and Early Permian caused many of the extensional structures to be uplifted and inverted. Extension and subsidence in the Late Permian through Jurassic resulted in the deposition of several kilometers of sediment, which led to thermally mature organic matter in shales of the Bowland and Hodder Formations and to the generation and migration of oil and gas. Up to 4 kilometers of uplift and erosion in the Paleogene (Anell and others, 2009) may have resulted in the breaching of conventional traps and the loss of oil and gas resources from conventional and continuous reservoirs. This uplift and possible loss of oil and gas is the major source of geologic uncertainty in the assessment of conventional and continuous oil and gas resources in the Midlands area.

\section{Total Petroleum Systems and Assessment Units}

In the Midlands area, the USGS defined the Bowland-Hodder Total Petroleum System (TPS), the Carboniferous TPS, and the Carboniferous Coal TPS. The Bowland-Hodder TPS encompasses oil or gas retained within shales of the Bowland and Hodder Formations

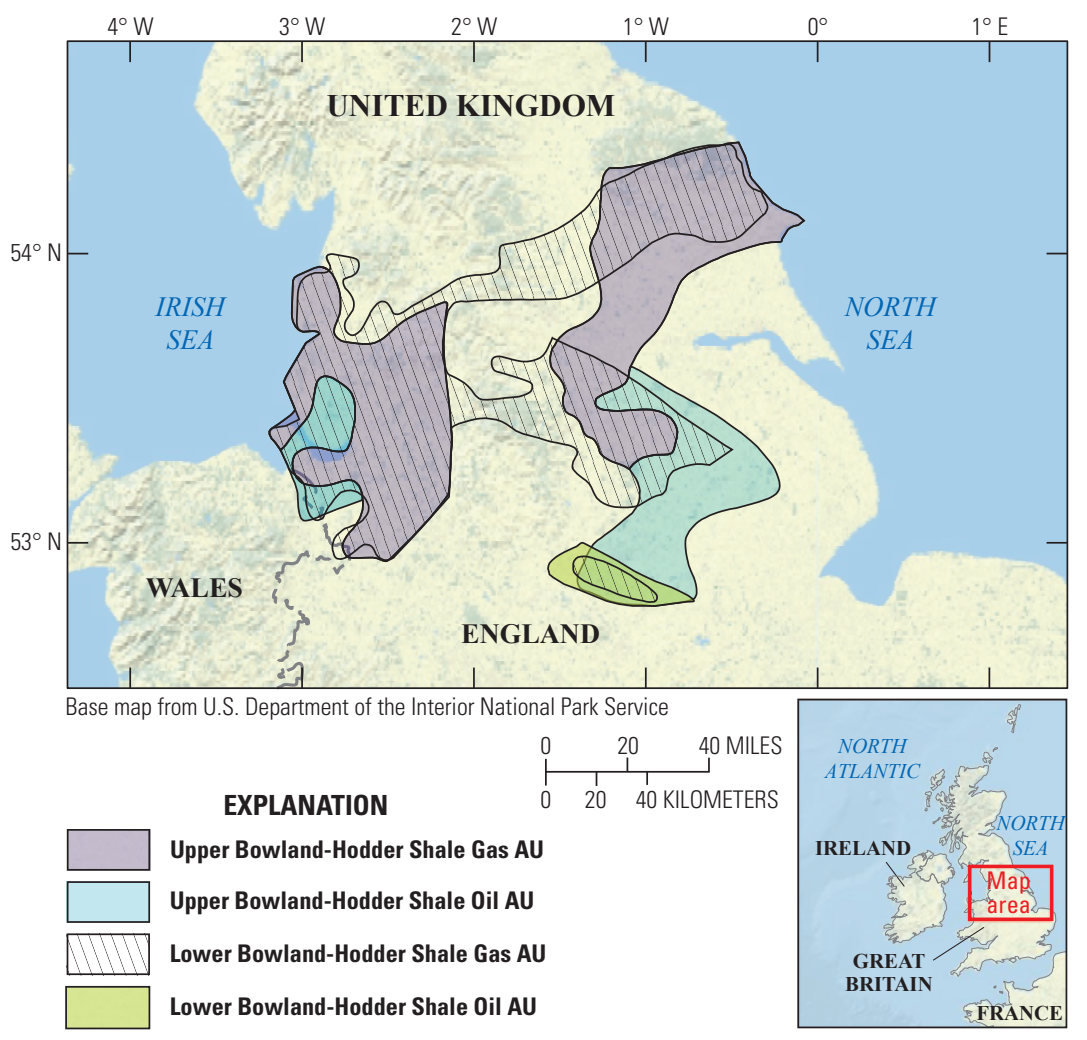

Figure 1. Location of four assessment units (AUs) in the Midlands area of England.

in the (1) Upper Bowland-Hodder Shale Gas Assessment Unit (AU), (2) Upper Bowland-Hodder Shale Oil AU, (3) Lower BowlandHodder Shale Gas AU, and (4) Lower Bowland-Hodder Shale Oil AU. Boundaries of potential shale-gas areas are modified from Andrews (2013). Shales in the lower part of the Bowland are as much as 3,000 meters (m) thick and contain both Type II and Type III kerogen. Shales in the upper part of the Bowland are as much as $900 \mathrm{~m}$ thick and contain predominantly Type II kerogen. Thermal maturity ranges upward to gas-generation levels in both shales (greater than 1.3 percent vitrinite reflectance), so present-day values of total organic carbon and hydrogen index are variable as these values are affected by maturation. The geologic model for potential shale-oil and shale-gas resources in the Bowland-Hodder TPS is for some portion of the oil or gas to have been retained within shales of the Bowland and Hodder Formations following Paleogene uplift and erosion. 


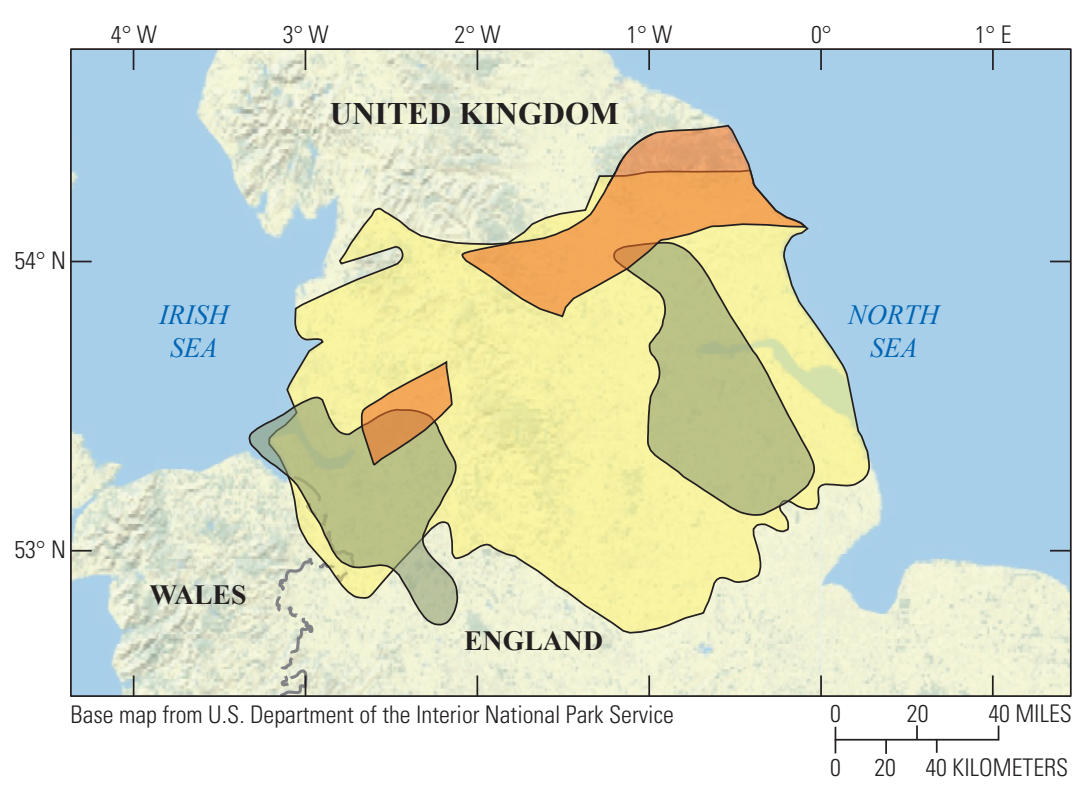

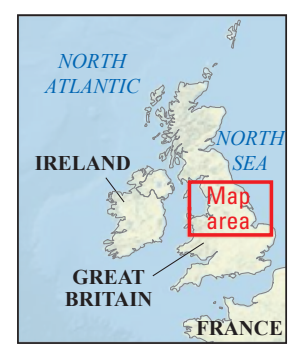

EXPLANATION

Namurian-Westphalian Tight Gas AU

Midlands Coalbed Gas AU

Midlands Conventional Oil and Gas AU

Figure 2. Location of three assessment units (AUs) in the Midlands area of England.

Table 1. Key input data for seven assessment units in the Midlands area of England.

[AU, assessment unit; \%, percent; EUR, estimated ultimate recovery per well; BCFG, billion cubic feet of gas; MMBO, million barrels of oil. Well drainage area, success ratio, and EUR are defined partly using U.S. shale-gas and shale-oil analogs. The average EUR input is the minimum, median, maximum, and calculated mean. Shading indicates not applicable]

\begin{tabular}{|c|c|c|c|c|c|c|c|c|}
\hline \multirow[b]{2}{*}{ Assessment input data-Continuous AUs } & \multicolumn{4}{|c|}{ Upper Bowland-Hodder Shale Gas AU } & \multicolumn{4}{|c|}{ Upper Bowland-Hodder Shale Oil AU } \\
\hline & $\begin{array}{l}\text { Mini- } \\
\text { mum }\end{array}$ & Mode & Maximum & $\begin{array}{c}\text { Calculated } \\
\text { mean }\end{array}$ & $\begin{array}{l}\text { Mini- } \\
\text { mum }\end{array}$ & Mode & Maximum & $\begin{array}{c}\text { Calculated } \\
\text { mean }\end{array}$ \\
\hline Potential production area of AU (acres) & 560 & $1,125,500$ & $2,251,000$ & $1,125,687$ & 560 & $1,007,000$ & $2,000,000$ & $1,002,520$ \\
\hline Average drainage area of wells (acres) & 100 & 140 & 180 & 140 & 80 & 140 & 200 & 140 \\
\hline Success ratio $(\%)$ & 10 & 50 & 90 & 50 & 10 & 50 & 90 & 50 \\
\hline Average EUR (BCFG, gas; MMBO, oil) & 0.1 & 0.4 & 1.3 & 0.447 & 0.04 & 0.08 & 0.2 & 0.086 \\
\hline AU probability & 1.0 & & & & 0.9 & & & \\
\hline \multirow[b]{2}{*}{ Assessment input data-Continuous AUs } & \multicolumn{4}{|c|}{ Lower Bowland-Hodder Shale Gas AU } & \multicolumn{4}{|c|}{ Lower Bowland-Hodder Shale Oil AU } \\
\hline & $\begin{array}{l}\text { Mini- } \\
\text { mum }\end{array}$ & Mode & Maximum & $\begin{array}{c}\text { Calculated } \\
\text { mean }\end{array}$ & $\begin{array}{l}\text { Mini- } \\
\text { mum }\end{array}$ & Mode & Maximum & $\begin{array}{c}\text { Calculated } \\
\text { mean }\end{array}$ \\
\hline Potential production area of AU (acres) & 600 & $1,470,500$ & $2,941,000$ & $1,470,700$ & 500 & 101,000 & 300,000 & 133,833 \\
\hline Average drainage area of wells (acres) & 60 & 120 & 180 & 120 & 60 & 80 & 140 & 93.3 \\
\hline Success ratio $(\%)$ & 10 & 50 & 90 & 50 & 10 & 50 & 90 & 50 \\
\hline Average EUR (BCFG, gas; MMBO, oil) & 0.1 & 0.4 & 1.3 & 0.447 & 0.01 & 0.04 & 0.15 & 0.046 \\
\hline AU probability & 0.9 & & & & 0.9 & & & \\
\hline \multirow[b]{2}{*}{ Assessment input data-Continuous AUs } & \multicolumn{4}{|c|}{ Namurian-Westphalian Tight Gas AU } & \multicolumn{4}{|c|}{ Midlands Coalbed Gas AU } \\
\hline & $\begin{array}{l}\text { Mini- } \\
\text { mum }\end{array}$ & Mode & Maximum & $\begin{array}{c}\text { Calculated } \\
\text { mean }\end{array}$ & $\begin{array}{l}\text { Mini- } \\
\text { mum }\end{array}$ & Mode & Maximum & $\begin{array}{c}\text { Calculated } \\
\text { mean }\end{array}$ \\
\hline Potential production area of AU (acres) & 480 & 800,000 & $1,206,000$ & 668,827 & 400 & 950,000 & $1,908,000$ & 952,800 \\
\hline Average drainage area of wells (acres) & 40 & 80 & 120 & 80 & 40 & 80 & 120 & 80 \\
\hline Success ratio $(\%)$ & 10 & 50 & 90 & 50 & 10 & 50 & 90 & 50 \\
\hline Average EUR (BCFG) & 0.08 & 0.4 & 1.2 & 0.44 & 0.08 & 0.25 & 1.0 & 0.29 \\
\hline AU probability & 1.0 & & & & 1.0 & & & \\
\hline \multirow[b]{2}{*}{ Assessment input data-Conventional AU } & \multicolumn{4}{|c|}{ Midlands Conventional Oil and Gas AU } & & & & \\
\hline & $\begin{array}{l}\text { Mini- } \\
\text { mum }\end{array}$ & Median & Maximum & $\begin{array}{c}\text { Calculated } \\
\text { mean }\end{array}$ & & & & \\
\hline Number of oil fields & 1 & 5 & 15 & 5.3 & & & & \\
\hline Number of gas fields & 1 & 20 & 60 & 21.3 & & & & \\
\hline Size of oil fields (MMBO) & 0.5 & 1.5 & 20 & 2.1 & & & & \\
\hline Size of gas fields (BCFG) & 3 & 9 & 80 & 11.3 & & & & \\
\hline AU probability & 1.0 & & & & & & & \\
\hline
\end{tabular}


The Carboniferous TPS is defined by oil and gas sourced from shales of the Bowland and Hodder Formations and possibly from coals of Westphalian age. Within this TPS are the Namurian-Westphalian Tight Gas AU and Midlands Conventional Oil and Gas AU. The geologic model for conventional accumulations in this AU is for oil and gas to have migrated into inversion structures that contain possible clastic and carbonate reservoirs. The geologic model for the continuous Namurian-Westphalian Tight Gas AU is for gas, generated from organic matter in shales of the Bowland and Hodder Formations and possibly from the Westphalian coals, to have migrated locally into and to have been trapped within low permeability, nonmarine to shallow-marine sandstones and siltstones of Namurian and Westphalian age. The AU area encompasses the Carboniferous Cleveland and Cheshire subbasins.

The Carboniferous Coal TPS is defined to encompass potential coalbed gas resources within Westphalian coals in two main areas of the Midlands, as mapped by the Department of Energy and Climate Change, United Kingdom (2013). In unmined areas, net coal thickness is as much as $40 \mathrm{~m}$, and coal rank is variable but ranges upward to anthracite. The Midlands
Coalbed Gas AU does not include areas of current coal mines, mined areas, or areas that produce coal-mine gas.

Assessment input data for seven assessment units are shown in table 1. For continuous assessment units, well drainage areas, success ratios, and estimated ultimate recoveries are guided by geologic analogs from the United States.

\section{Undiscovered Resources Summary}

The USGS quantitatively assessed undiscovered continuous and conventional oil and gas resources within the Midlands area of England (table 2). For undiscovered resources, the estimated mean totals are 319 million barrels of oil (MMBO), with an F95-F5 range from 4 to 753 MMBO; 8,254 billion cubic feet of gas (BCFG), or 8.3 trillion cubic feet of gas, with an F95-F5 range from 1,235 to 19,696 BCFG; and 54 million barrels of natural gas liquids (MMBNGL) with an F95-F5 range from 6 to 133 MMBNGL. Of the total mean oil resources of $319 \mathrm{MMBO}$, about 97 percent, or $308 \mathrm{MMBO}$, is potential shaleoil resources; and of the mean total gas resources of $8,254 \mathrm{BCFG}$, about 97 percent, or 8,006 BCFG, are shale gas (54 percent), tight gas (22 percent), and coalbed gas (21 percent) resources.

Table 2. Results for seven assessment units in the Midlands area of England.

[MMBO, million barrels of oil; BCFG, billion cubic feet of gas; NGL, natural gas liquids; MMBNGL, million barrels of natural gas liquids. Results shown are fully risked estimates. For gas accumulations, all liquids are included in the NGL category. F95 represents a 95-percent chance of at least the amount tabulated; other fractiles are defined similarly. Fractiles are additive under the assumption of perfect positive correlation. Shading indicates not applicable]

\begin{tabular}{|c|c|c|c|c|c|c|c|c|c|c|c|c|c|c|}
\hline \multirow{3}{*}{$\begin{array}{l}\text { Total petroleum systems } \\
\text { and assessment units (AUs) }\end{array}$} & \multirow{3}{*}{$\begin{array}{c}\text { AU } \\
\text { prob- } \\
\text { ability }\end{array}$} & \multirow{3}{*}{$\begin{array}{c}\text { Accu- } \\
\text { mulation } \\
\text { type }\end{array}$} & \multicolumn{12}{|c|}{ Total undiscovered resources } \\
\hline & & & \multicolumn{4}{|c|}{ Oil (MMBO) } & \multicolumn{4}{|c|}{ Gas (BCFG) } & \multicolumn{4}{|c|}{ NGL (MMBNGL) } \\
\hline & & & F95 & F50 & F5 & Mean & F95 & F50 & F5 & Mean & F95 & F50 & F5 & Mean \\
\hline \multicolumn{15}{|c|}{ Bowland-Hodder Total Petroleum System } \\
\hline $\begin{array}{l}\text { Upper Bowland-Hodder } \\
\text { Shale Gas AU }\end{array}$ & 1.0 & Gas & & & & & 368 & 1,486 & 4,209 & 1,779 & 3 & 12 & 35 & 14 \\
\hline $\begin{array}{l}\text { Upper Bowland-Hodder } \\
\text { Shale Oil AU } \\
\end{array}$ & 0.9 & Oil & 0 & 250 & 653 & 279 & 0 & 148 & 400 & 167 & 0 & 0 & 1 & 1 \\
\hline \begin{tabular}{|l} 
Lower Bowland-Hodder \\
Shale Gas AU \\
\end{tabular} & 0.9 & Gas & & & & & 0 & 2,076 & 6,252 & 2,465 & 0 & 25 & 76 & 30 \\
\hline \begin{tabular}{|l} 
Lower Bowland-Hodder \\
Shale Oil AU \\
\end{tabular} & 0.9 & Oil & 0 & 23 & 78 & 29 & 0 & 14 & 48 & 17 & 0 & 0 & 0 & 0 \\
\hline \multicolumn{15}{|c|}{ Carboniferous Total Petroleum System } \\
\hline \begin{tabular}{|l} 
Namurian-Westphalian \\
Tight Gas AU \\
\end{tabular} & 1.0 & Gas & & & & & 403 & 1,590 & 4,179 & 1,850 & 2 & 6 & 17 & 7 \\
\hline \multicolumn{15}{|c|}{ Carboniferous Coal Total Petroleum System } \\
\hline Midlands Coalbed Gas AU & 1.0 & Gas & & & & & 343 & 1,411 & 4,179 & 1,728 & 0 & 0 & 0 & 0 \\
\hline $\begin{array}{l}\text { Total undiscovered } \\
\text { continuous resources }\end{array}$ & & & 0 & 273 & 731 & 308 & 1,114 & 6,725 & 19,267 & 8,006 & 5 & 43 & 129 & 52 \\
\hline \multicolumn{15}{|c|}{ Carboniferous Total Petroleum System } \\
\hline \multirow{2}{*}{$\begin{array}{l}\text { Midlands Conventional Oil } \\
\text { and Gas AU }\end{array}$} & \multirow{2}{*}{1.0} & Oil & 4 & 10 & 22 & 11 & 3 & 6 & 13 & 7 & 0 & 0 & 0 & 0 \\
\hline & & Gas & & & & & 118 & 226 & 416 & 241 & 1 & 2 & 4 & 2 \\
\hline \begin{tabular}{|c|}
$\begin{array}{c}\text { Total undiscovered } \\
\text { conventional resources }\end{array}$ \\
\end{tabular} & & & 4 & 10 & 22 & 11 & 121 & 232 & 429 & 248 & 1 & 2 & 4 & 2 \\
\hline $\begin{array}{l}\text { Total undiscovered } \\
\text { resources }\end{array}$ & & & 4 & 283 & 753 & 319 & 1,235 & 6,957 & 19,696 & 8,254 & 6 & 45 & 133 & 54 \\
\hline
\end{tabular}




\section{References Cited}

Andrews, I.J., 2013, The Carboniferous Bowland Shale gas study - Geology and resource estimation: London, United Kingdom, Department of Energy and Climate Change, prepared by British Geological Survey [London, United Kingdom], 64 p., accessed February 26, 2018, at https://www.ogauthority.co.uk/media/2782/bgs_decc_ bowlandshalegasreport_main_report.pdf.

Anell, I., Thybo, H., and Artemieva, I.M., 2009, Cenozoic uplift and subsidence in the North Atlantic region - Geological evidence revisited: Tectonophysics, v. 474, nos. 1-2, p. 78-105.

Corfield, S.M., Gawthorpe, R.L., Gage, M., Fraser, A.J., and Besly, B.M., 1996, Inversion tectonics of the Variscan foreland of the British Isles: Journal of the Geological Society [London, United Kingdom], v. 153, p. 17-32.

Department of Energy and Climate Change, United Kingdom, 2013, The unconventional hydrocarbon resources of Britain's onshore basins - Coalbed methane (CBM): London, United Kingdom, Department of Energy and Climate Change, prepared by British Geological Society [London, United Kingdom], 40 p., accessed February 26, 2018, at https://www. ogauthority.co.uk/media/1694/promote_uk_cbm_2012.pdf.

Fauchille, A.L., Ma, L., Rutter, E., Chandler, M., Lee, P.D., and Taylor, K.G., 2017, An enhanced understanding of the basinal Bowland shale in Lancaster (UK), through microtextural and mineralogical observations: Marine and Petroleum Geology, v. 86 , p. $1374-1390$.

Fraser, A.J., and Gawthorpe, R.L., 1990, Tectono-stratigraphic development and hydrocarbon habitat of the Carboniferous in northern England: Geological Society, London, Special Publications, v. 55, p. 49-86.
Gross, D., Sachsenhofer, R.F., Bechtel, A., Pytlak, L., Rupprecht, B., and Wegerer, E., 2015, Organic geochemistry of Mississippian shales (Bowland Shale Formation) in central Britain - Implications for depositional environment, source rock and gas shale potential: Marine and Petroleum Geology, v. 59 , p. $1-21$.

Hennissen, J.A.I., Hough, E., Vane, C.H., Leng, M.J., Kemp, S.J., and Stephenson, M.H., 2017, The prospectivity of a potential shale gas play-An example from the southern Pennine Basin (central England, UK): Marine and Petroleum Geology, v. 86, p. 1047-1066.

Raji, M., Cornford, C., Pather, A., and Satterfield, D., 2015, Unconventional oil and gas potential of the Widmerpool Gulf in the East Midlands Province of England: Unconventional Resources Technology Conference, Denver, Colo., August 12-14, 2013, Proceedings, p. 949-961, accessed February 26, 2018, at https://library.seg.org/doi/abs/10.1190/ urtec2013-097.

Whitelaw, P., Uguna, C., Stevens, L., Meredith, W., Snape, C.E., Vane, C., Moss-Hayes, V., and Carr, A.D., 2017, An evaluation of shale gas potential in the Bowland Shale, UK using sequential high water pressure pyrolysis and methane adsorption: American Association of Petroleum Geologists, Search and Discovery Article No. 51450, December 26, 2017, 17 p., accessed February 26, 2018, at http://www.searchanddiscovery.com/pdfz/ documents/2017/51450whitelaw/ndx_whitelaw.pdf.html.

Yang, S., Horsfield, B., Mahlstedt, N., Stephenson, M., and Könitzer, S., 2016, On the primary and secondary petroleum generating characteristics of the Bowland Shale, northern England: Journal of the Geological Society [London, United Kingdom], v. 173, no. 2, p. 292-305.

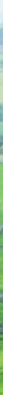

\section{Midlands Area Assessment Team}

Christopher J. Schenk, Marilyn E. Tennyson, Tracey J. Mercier, Cheryl A. Woodall, Thomas M. Finn, Stephanie B. Gaswirth, Phuong A. Le, Michael E. Brownfield, Kristen R. Marra, and Heidi M. Leathers-Miller

\section{For More Information}

Assessment results are also available at the USGS Energy Resources Program website at https://energy.usgs.gov. 